\title{
A Temperature-sensitive Cell-cycle Mutant of Mammalian Cells, tsJT16, is Defective in a Function Operating Soon after Growth Stimulation
}

\author{
Tsuyoshi Takasuka ${ }^{1}$, Jun Ninomiya-Tsuji ${ }^{2}$, Mihoko Sakayama ${ }^{1}$, Sadahiko Ishibashi ${ }^{1}$, and Toshinori \\ Ide $^{1 \dagger}$ \\ ${ }^{1}$ Department of Physiological Chemistry, Hiroshima University School of Medicine, Kasumi 1-2-3, Hiroshima \\ City, Hiroshima 734, Japan and ${ }^{2} D N A X$ Research Institute for Molecular and Cellular Biology, 901 California \\ Avenue, Palo Alto, Ca 94304, U.S.A.
}

Key words: cell cycle/ts mutant $/ \mathrm{G}_{0}-\mathrm{S}$ transition early events/signal transduction

\begin{abstract}
$A B S T R A C T$. A temperature-sensitive cell-cycle mutant, $t s J T 16$, which has been isolated from Fischer rat fibroblasts, was defective in the function(s) that operated soon after growth stimulation. When $\mathrm{G}_{0}$-arrested $t s-$ JT16 was stimulated to proliferate, it entered the $S$ phase after $12-15 \mathrm{~h}$ at $34^{\circ} \mathrm{C}$ but failed to do so at $40^{\circ} \mathrm{C}$. The function mutated in $t s J T 16$ was required to be normal for the first $4 \mathrm{~h}$ or less for cells to transit from the $G_{0}$ to $S$ phase. The induction of cell-cycle-dependent genes such as $c$-fos, $c$-myc and ornithine decarboxylase was observed at both temperatures after growth stimulation. Although an increase in total protein synthesis occurred at both temperatures after growth stimulation, synthesis of one protein (p70) (pI 7.8 and $\mathrm{Mr} 70,000)$ was inhibited at $40^{\circ} \mathrm{C}$. Synthesis of $\mathrm{p} 70$ was negligible in $\mathrm{G}_{0}$-arrested cells and blocked by actinomycin $\mathrm{D}$ in serum-stimulated cells at $34^{\circ} \mathrm{C}$. These results suggest that $t s J T 16$ has a $t s$ defect in one of the signal transduction processes to induce gene activation. $t s \mathrm{JT} 16$ was also defective in progression of the $\mathrm{G}_{1}$ phase of growing cells, consistent with the previous results in which growth stimuli were required at $\mathbf{G}_{\mathbf{1}}$ for continuation of proliferation.
\end{abstract}

A large body of evidence has been accumulating that diffent growth factors activate signal transduction pathways via different second messenger molecules and result in an induction of several cell-cycle-dependent genes whose products drive $\mathrm{G}_{0}$-arrested cells toward the $\mathrm{S}$ phase. Although it goes without saying that such a biochemical approach as stepwise analysis of a signal transduction process is fruitful in elucidating the mechanisms for initiation of cell proliferation, this approach has two major limitations: 1 ) it is less suitable for finding a new or unexpected sequence in signal transduction processes, and 2) it is not always easy to discriminate an essential or prerequisite event for cells to initiate proliferation from nonessential or accompanied events occurring in growth-stimulated cells.

The use of $t s$ mutant cells theoretically complements these limitations, although it has its own limitations. A library of cell-cycle $t s$ mutants should include clones defective in genes which are concerned with a wide variety of known and unknown steps of signal transduction processes for growth induction. In a $t s$ mutant that fails to initiate proliferation at the nonpermissive temperature, the mutated function should be concerned with an

\footnotetext{
$\dagger$ To whom correspondence and reprint requests should be addressed.
}

essential event for cell proliferation, leaving aside whether it acts directly or indirectly and specifically or nonspecifically. To date, no $t s$ mutant of mammalian origin has been reported which had a $t s$ mutation in early events after growth stimulation, in spite of the isolation of a large number of cell-cycle $t s$ mutant clones (1).

In the present paper, we describe the first cell-cycle $t s$ mutant of mammalian origin which has a defect in a function operating in the early stage, within $4 \mathrm{~h}$ or less, after growth stimulation. Although the precise biochemical step at which the mutated function operates is still unidentified, it is likely to be in one of the signal transduction processes from the cell surface to nuclei.

\section{MATERIALS AND METHODS}

Cells and cultyres. tsIT16 was isolated as previously reported '(7) from Fischer rat embryo fibroblast line 3Y1 (9) and frozen-stored without further characterization. The cells were cultured in Dulbecco's modified Eagle's medium (DMEM, Nissui, Tokyo) supplemented with $10 \%$ fetal bovine serum (M.A. Bioproducts, Md), penicillin G (100 units/ml), and streptomycin sulfate $(100 \mu \mathrm{g} / \mathrm{ml})$. 3Y1 was maintained at $37^{\circ} \mathrm{C}$, and $t s \mathrm{JT} 16$ was at the permissive temperature, $34^{\circ} \mathrm{C}$. The nonpermissive temperature for $t s \mathrm{JT} 16$ was $40^{\circ} \mathrm{C}$. Routine 
checking by autoradiography (14) and DAPI staining (16) revealed no contamination with mycoplasmas.

Kinetic analysis. The cells were $\mathrm{G}_{0}$-arrested by culturing a confluent monolayer in serum-free DMEM for 2-3 days. Arrested cells were stimulated for an induction of the $\mathrm{G}_{0}-\mathrm{S}$ transition by replacing the culture fluid with fresh medium containing $10 \%$ fetal bovine serum. The progression toward the $\mathrm{S}$ phase was monitored by either autoradiography or by measuring radioactivity in acid-insoluble materials after labeling cells with $\left[{ }^{3} \mathrm{H}\right]$ thymidine $(37 \mathrm{KBq} / \mathrm{ml}, 74 \mathrm{GBq} / \mathrm{m}$ mol, Amersham) as reported previously (11). Frequency of mitotic cells was measured under a microscope after fixation and Giemsa staining.

Northern blot analysis. Northern blot analysis was carried out, as described previously (8), by isolating total cytoplasmic RNA, size fractionating on agarose gel, transferring to nitrocellulose filter, hybridizing to nick-translated probes (2$4 \times 10^{8} \mathrm{cpm} / \mu \mathrm{g} \mathrm{DNA}$ ), and exposing to Kodak X-Omat AR film. The plasmids used were pc3sp6vfos (carrying v-fos gene in a Riboprobe vector, a kind gift of Dr. S. Rittling), c-myc54 (carrying mouse c-myc gene, a kind gift of Dr. L. Kaszmarek) and pODC934 (carrying a mouse ornithine decarboxylase cDNA sequence (2), a kind gift of Dr. R. Baserga).

Protein synthesis and two-dimensional polyacrylamide gel electrophoresis. Cells in 35-mm plastic dishes were labeled for $1 \mathrm{~h}$ with $\left[{ }^{3} \mathrm{H}\right]$ leucine $(111 \mathrm{KBq} / \mathrm{ml}, 185 \mathrm{GBq} / \mathrm{m} \mathrm{mol}$, New England Nuclear) in medium deficient in leucine with or without $10 \%$ dialyzed serum. After labeling, the cells were washed with phosphate-buffered saline and lyzed in $0.5 \mathrm{~N}$ $\mathrm{KOH}$. The lysate was kept overnight at room temperature and then precipitated with trichloroacetic acid. Radioactivities in acid-precipitable materials collected on a GF/c filter were measured in a liquid scintillation spectrometer.

For two-dimensional polyacrylamide gel electrophoresis (2D PAGE) of cellular protein, the cells plated in $60-\mathrm{mm}$ dishes were labeled for $2 \mathrm{~h}$ with $\left[{ }^{35} \mathrm{~S}\right]$ methionine (TRAN ${ }^{35} \mathrm{~S}-\mathrm{LABEL}$, $1.1 \mathrm{MBq} / \mathrm{ml}, \mathrm{ICN}$ ) in DMEM deficient in methionine with or without $10 \%$ dialyzed serum. The cells were then washed with cold phosphate-buffered saline and solubilized in a solution containing $0.3 \%$ sodium laurylsulfate and $10 \%$ 2-mercaptoethanol. DNA was digested by incubating with DNase I $(80 \mu \mathrm{g} / \mathrm{ml})$ for $5 \mathrm{~min}$ on ice. The lysate was mixed with solid urea (final concentration; $8.5 \mathrm{M}$ ) and an equal volume of a solution containing $8.5 \mathrm{M}$ urea, $5 \% 2$-mercaptoethanol, and $4 \%$ Nonidet P-40, and then applied on the first-dimensional gel. $\mathrm{pH}$ gradient was formed in the gel by Bio Lytes (BioRad): $0.4 \%$ pH 3-7, $0.8 \%$ pH 5-7, and $0.8 \%$ pH 6-8. Twodimensional gel electrophoresis was performed in $10 \%$ polyacrylamide gel according to the method of O'Farrell (10). After the run, the gels were fixed, stained with Coomassie brilliant blue, destained, impregnated with EN ${ }^{3} \mathrm{HANCE}$ (New England Nuclear), dried and exposed to Kodak X-Omat AR-5 film. (a)

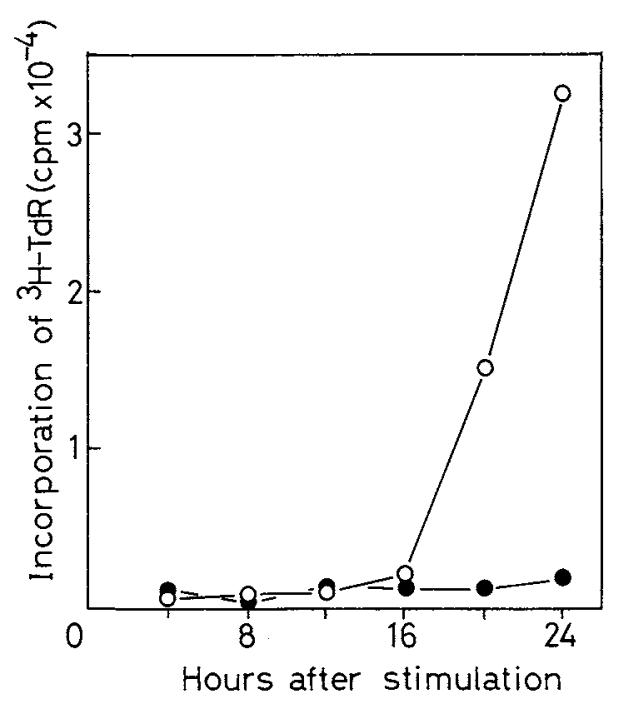

(b)

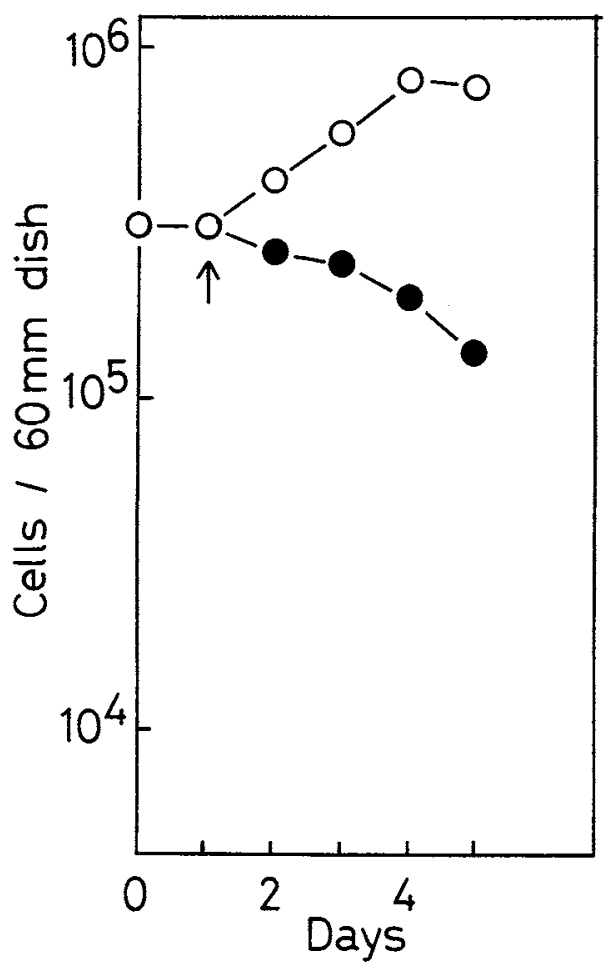

Fig. 1. Resumption of proliferation of $t s \mathrm{JT} 16$ after serum stimulation. Confluent monolayers of $t s$ JT16 cells were growth-arrested in serum-free medium for 2 days and were stimulated to proliferate with serum. (a) Entrance into the $S$ phase after serum stimulation of $G_{0^{-}}$ arrested $t$ s.JT 16 cells. The stimulated cells were cultured at $34^{\circ} \mathrm{C}(O)$ or $40^{\circ} \mathrm{C}(\bullet)$ in the presence of $\left[{ }^{3} \mathrm{H}\right]$ thymidine. At the indicated times, the cells were fixed and the radioactivity was measured. (b) Changes in cell number following serum stimulation. The cells were stimulated at day 1 (arrow) and cultured at $34^{\circ} \mathrm{C}(\bigcirc)$ or $40^{\circ} \mathrm{C}(\bullet)$. 


\section{RESULTS}

Kinetic analysis. $t$ JT16 cells began to enter the S phase at $12-15 \mathrm{~h}$ poststimulation at $34^{\circ} \mathrm{C}$, but at $40^{\circ} \mathrm{C}$, neither entered the $\mathrm{S}$ phase (Fig. 1a) nor resumed proliferation (Fig. 1b). To determine the stage (execution point) at which progression of the cell cycle was blocked at $40^{\circ} \mathrm{C},\left[{ }^{3} \mathrm{H}\right]$ thymidine was added at the time of serum stimulation, and the cells were cultured at $34^{\circ} \mathrm{C}$ for various periods of time. Then the culture temperature was shifted up to $40^{\circ} \mathrm{C}$ until the end of the experiments at $34 \mathrm{~h}$ after stimulation, and the cultures were processed for autoradiography. Only the cells whose culture temperature was increased earlier than $4 \mathrm{~h}$, or earlier than $2 \mathrm{~h}$ in another experiment, after serum stimulation were blocked against the $\mathrm{G}_{0}-\mathrm{S}$ transition (Fig. 2). These results indicated that the gene mutated in $t s \mathrm{JT} 16$ was required to operate normally only at a relatively early stage (at most, $4 \mathrm{~h}$ after serum stimulation) in the $\mathrm{G}_{0}-\mathrm{S}$ transition.

When serum-stimulated $t s \mathrm{JT} 16$ cells were cultured at $40^{\circ} \mathrm{C}$ for various periods of time and the culture temperature was shifted down to $34^{\circ} \mathrm{C}$, the entrance into the $\mathrm{S}$ phase was delayed for the same periods as for those cultured at $40^{\circ} \mathrm{C}$ (Fig. 3). This indicated that the cells remained at the execution point as long as they were maintained at $40^{\circ} \mathrm{C}$. When the cells were cultured for

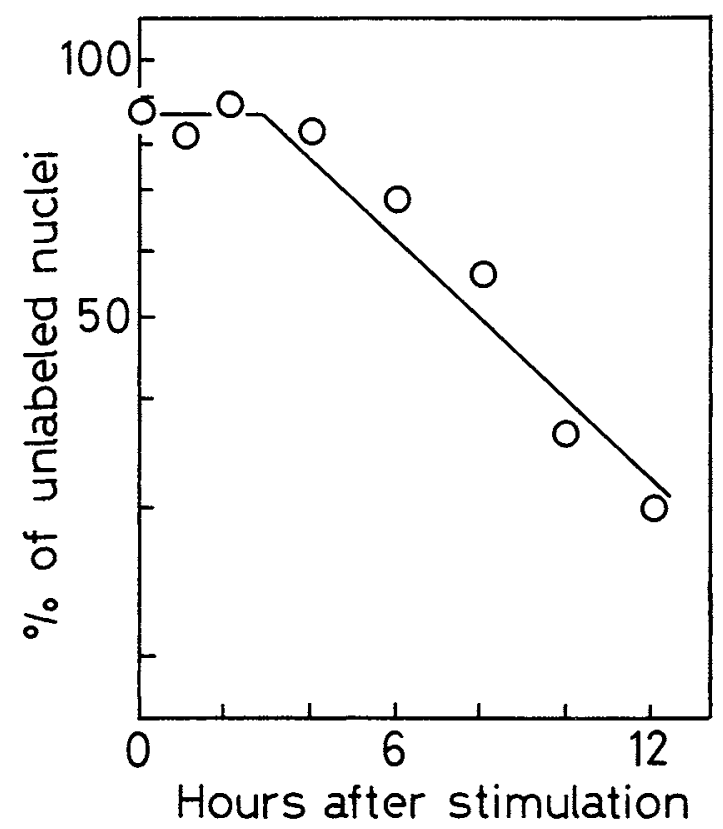

Fig. 2. Execution point of $t s \mathrm{JT} 16 . \mathrm{G}_{0}$-arrested $t s \mathrm{JT} 16$ cells were stimulated with serum and cultured in the presence of $\left[{ }^{3} \mathrm{H}\right]$ thymidine at $34^{\circ} \mathrm{C}$. At the indicated times, the culture temperature was increased to $40^{\circ} \mathrm{C}$ until the end of the experiments, $34 \mathrm{~h}$ after serum stimulation. The cultures were fixed and processed for autoradiography. much longer periods at $40^{\circ} \mathrm{C}$, they began to die

When $t$ JTT 16 cells grown at $34^{\circ} \mathrm{C}$ in a $\log$ phase were transferred to $40^{\circ} \mathrm{C}$, they stopped growing and began to die (Fig. 4). To determine the cell phase where $t s$ JT16 was blocked at $40^{\circ} \mathrm{C}$, the progression of cells in $\mathrm{S}, \mathrm{G}_{2}$, and $\mathrm{M}$ phases was analyzed. $t s \mathrm{JT} 16$ cells were synchronized at the $\mathrm{G}_{1}-\mathrm{S}$ boundary at $34^{\circ} \mathrm{C}$ by the successive block with hydroxyurea and excess thymidine. Upon release from the block, they passed through the $\mathrm{S}$ phase (Fig. 5a) and $\mathrm{M}$ phase (Fig. 5b) at both $34^{\circ} \mathrm{C}$ and $40^{\circ} \mathrm{C}$, except that the second peak of the $\mathrm{S}$ phase $(15 \mathrm{~h}$ after the removal of hydroxyurea) was abolished at $40^{\circ} \mathrm{C}$. These results indicated that the progression of $t s-$ JT16 cells in the cell cycle was not blocked at the $S, G_{2}$, and $M$ phases but was probably blocked at the $G_{1}$ phase. The precise execution point in the $G_{1}$ phase of the growth cycle was not determined because of a viability loss at $40^{\circ} \mathrm{C}$.

Induction of cell-cycle-dependent genes. Accumulation of cell-cycle-dependent mRNAs was analyzed by Northern blot of total cytoplasmic RNA from cells stimulated from $\mathrm{G}_{0}$ with serum. c-fos, c-myc, and ODC were reported to be induced in serum-stimulated $3 \mathrm{Y} 1$ cells at both temperatures (8) and were selected as examples of immediate early-, early-, and late-inducible genes, respectively. In $t s \mathrm{JT} 16$ cells, $c$-fos mRNA accu-

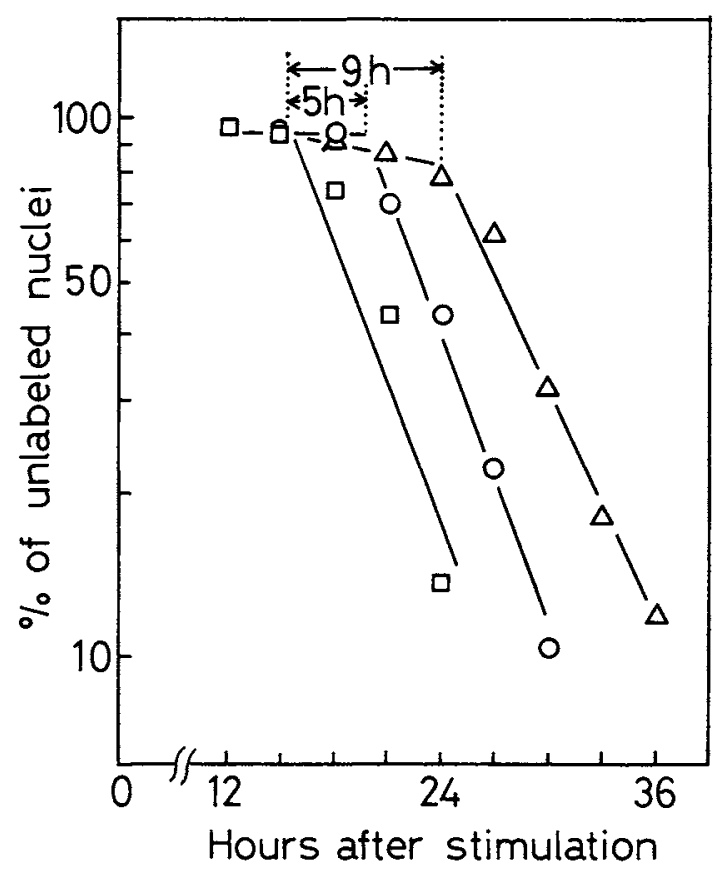

Fig. 3. Delay of cell entry into the $S$ phase by culturing at $40^{\circ} \mathrm{C} . \mathrm{G}_{0^{-}}$ arrested $t s J T 16$ cells were stimulated with serum and cultured in the presence of $\left[{ }^{3} \mathrm{H}\right]$ thymidine. The cells were cultured at $40^{\circ} \mathrm{C}$ for $6 \mathrm{~h}(\mathrm{O})$ or for $12 \mathrm{~h}(\triangle)$ after the stimulation and then maintained at $34^{\circ} \mathrm{C}$, or cultured at $34^{\circ} \mathrm{C}$ throughout $(\square)$. After $36 \mathrm{~h}$, they were fixed and processed for autoradiography. 
mulated quickly at $34^{\circ} \mathrm{C}$ after serum stimulation with a peak at $30 \mathrm{~min}$ and then decreased (Fig. 6a). The accumulation of $c-m y c$ mRNA increased at $34^{\circ} \mathrm{C}$ with a broad peak at around $4 \mathrm{~h}$ (Fig. 6b). An accumulation of mRNA also occurred at $40^{\circ} \mathrm{C}$ with some differences in peak time. The accumulation of ODC mRNA began at $4 \mathrm{~h}$ and peaked at more than $8 \mathrm{~h}$ after serum stimulation at $34^{\circ} \mathrm{C}$ (Fig. 6c). It was unexpected that ODC mRNA also accumulated at $40^{\circ} \mathrm{C}$ with a peak later than $8 \mathrm{~h}$ (Fig. 6c), because the kinetic experiment showed that a progression of $t s \mathrm{JT} 16$ cells in the $\mathrm{G}_{0}-\mathrm{S}$ transition was blocked at $40^{\circ} \mathrm{C}$ at the execution point, $2-4 \mathrm{~h}$ after serum stimulation.

Induction of protein synthesis. Partial inhibition of protein synthesis was known to block progression of the $\mathrm{G}_{1}$ phase in growing cells as well as the $\mathrm{G}_{0}-\mathrm{S}$ transition in serum-stimulated $G_{0}$ cells $(3,4,15,17)$. To see whether the $t s$ mutation of $t s$ JT16 results in an inhibition of protein synthesis, incorporation of $\left[{ }^{3} \mathrm{H}\right]$ leucine into acid-insoluble materials was measured after serum stimulation at both temperatures. No inhibition was observed at $40^{\circ} \mathrm{C}$ (Fig. 7).

We then analyzed cellular proteins synthesized $1-3 \mathrm{~h}$ after serum stimulation by 2-D PAGE. Although an increase or a decrease was observed after serum stimula-

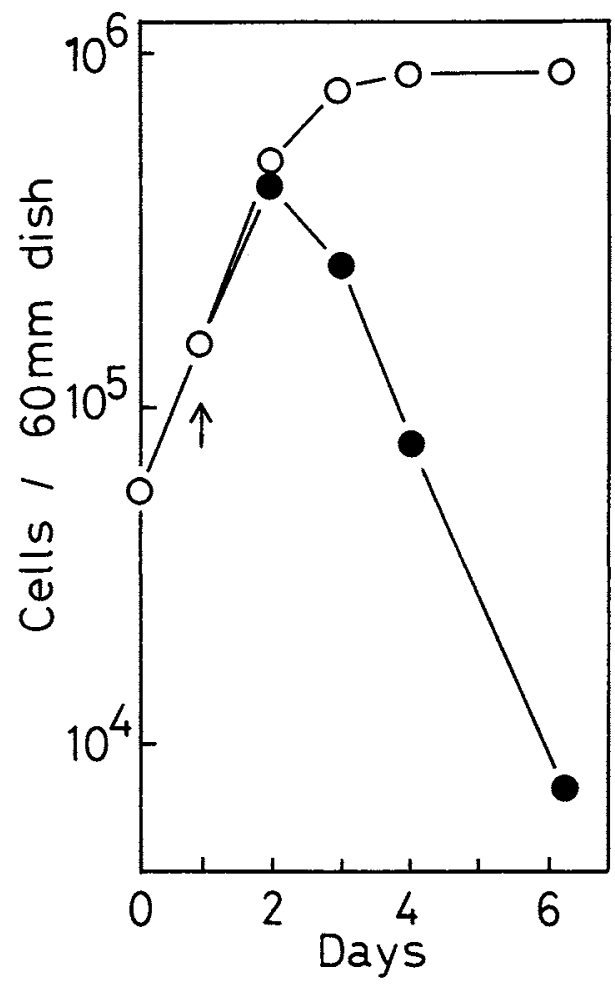

Fig. 4. Growth curve of tsJT16. tsJT16 cells were plated and cultured at $34^{\circ} \mathrm{C}$. On the day indicated by the arrow, the culture temperature was shifted to $40^{\circ} \mathrm{C}(\bullet)$ or unchanged $(0)$. tion in several $\left[{ }^{35} \mathrm{~S}\right]$ methionine-labeled protein spots, most of these changes were observed similarly in both samples from cells stimulated at $34^{\circ} \mathrm{C}$ and $40^{\circ} \mathrm{C}$. Among them, one protein spot (p70) (pI 7.8 and molecular weight 70,000 ) was clearly observed in $t s \mathrm{JT} 16$ cells stimulated at $34^{\circ} \mathrm{C}$ (Fig. 8a), but it was not detected or scarcely detected in samples from unstimulated cells (Fig. 8b) or those stimulated at $40^{\circ} \mathrm{C}$ (Fig. 8c). In $3 \mathrm{Y} 1$, a parental line of $t s \mathrm{JT} 16, \mathrm{p} 70$ increased following serum stimulation at both temperatures (Figs. $8 \mathrm{~d}$ and e). An increase in p70 synthesis was likely to be transcriptionally controlled, because it was blocked when $t s$ JT16 cells were stimulated at $34^{\circ} \mathrm{C}$ in the presence of actinomycin $\mathrm{D}$ (Fig. 8f). These results indicated that an induction of some cell-cycle-dependent genes was intact but that of other genes such as p70 was blocked in $t s$ JT 16 cells after the stimulation with serum at $40^{\circ} \mathrm{C}$.

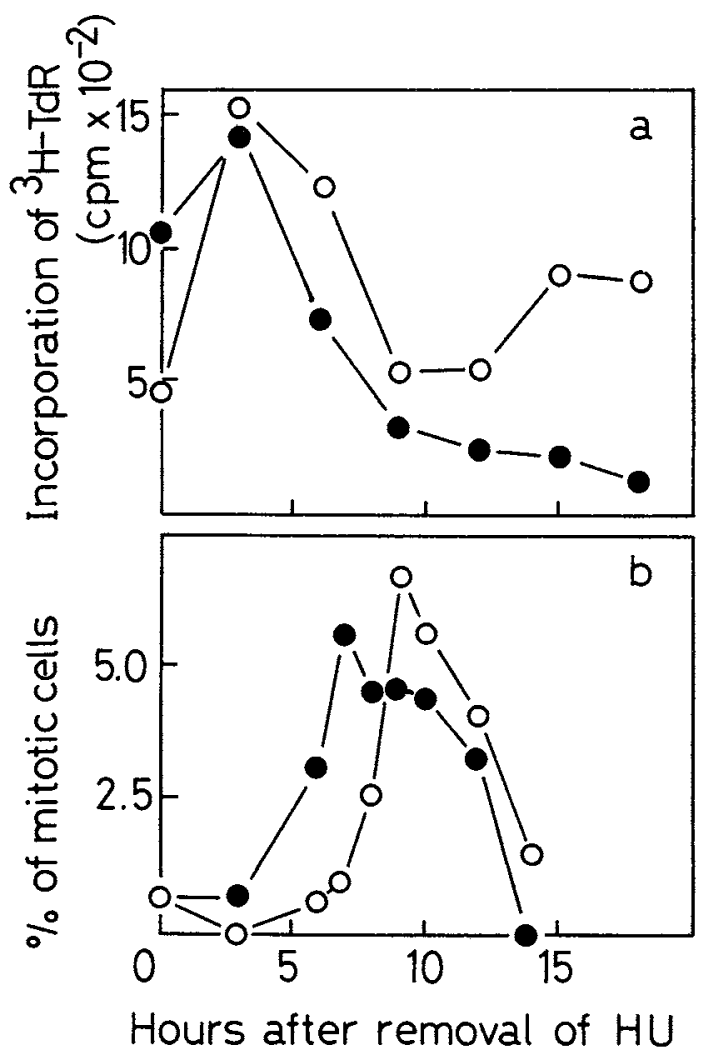

Fig. 5. The progression of the $S$ and $M$ phases at $34^{\circ} \mathrm{C}$ and $40^{\circ} \mathrm{C}$. Exponentially growing $t s \mathrm{JT} 16$ cells were treated at $34^{\circ} \mathrm{C}$ with $2.5 \mathrm{mM}$ of thymidine for $24 \mathrm{~h}$. After removal of thymidine, they were cultured for $10 \mathrm{~h}$ and treated with $1 \mathrm{mM}$ of hydroxyurea. Hydroxyurea was removed at time 0 and the cells were cultured at $34^{\circ} \mathrm{C}(0)$ or $40^{\circ} \mathrm{C}(\bullet)$. (a) Progression of the $\mathrm{S}$ phase. The cells were pulse-labeled with $\left[{ }^{3} \mathrm{H}\right]$ thymidine for $1 \mathrm{~h}$ at the indicated times and then measured for radioactivity. (b) Progression of the $M$ phase. The frequency of mitotic cells was measured by counting about 300 cells under a microscope. 


\section{DISCUSSION}

The results reported here are summarized as follows: 1) when $G_{0}$-arrested $t s$ JT16 cells were stimulated for growth with serum, the execution point was determined to be within $4 \mathrm{~h}$, indicating that the mutated function in $t s \mathrm{JT} 16$ is required for the first $4 \mathrm{~h}$ or less for cells to transit from the $G_{0}$ to $S$ phase; 2) progression of the $G_{1}$ phase in the growth cycle was temperature sensitive, while that of the $S, G_{2}$, and $M$ phases was not; 3 ) when $\mathrm{G}_{0}$-arrested $t s \mathrm{JT} 16$ cells were stimulated for growth at $40^{\circ} \mathrm{C}$, the accumulation of mRNAs from such cellcycle-dependent genes as $c$-fos, $c-m y c$, and ODC was almost identical with that observed at $34^{\circ} \mathrm{C}$, while the synthesis of a protein, p70, was inhibited; and 4) induc-

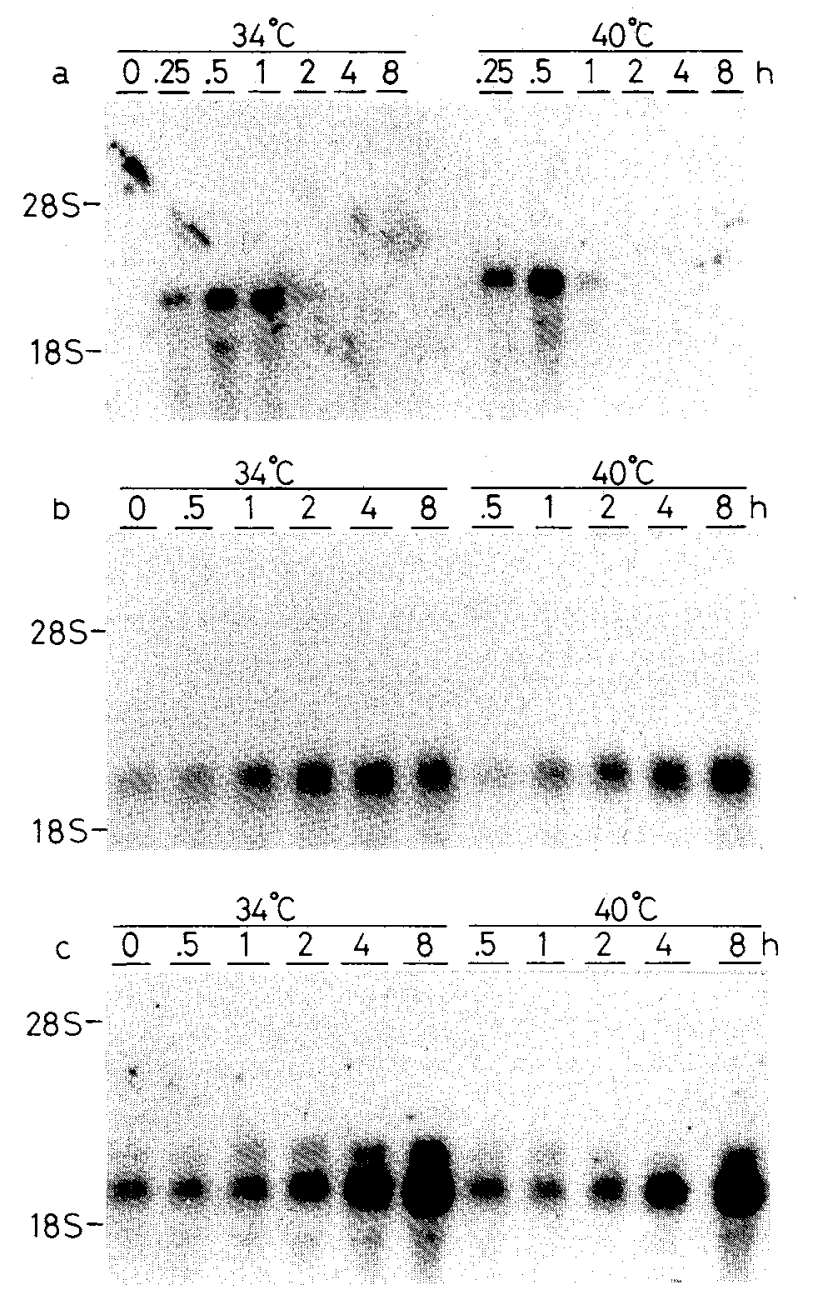

Fig. 6. Northern blot analysis of $c$-fos, $c-m y c$ and ornithine decarboxylase mRNAs. $\mathrm{G}_{0}$-arrested $t s \mathrm{JT} 16$ cells were serumstimulated and cultured for indicated periods at $34^{\circ} \mathrm{C}$ or $40^{\circ} \mathrm{C}$. Cytoplasmic total RNA was extracted and analyzed as described in Methods (15 $\mu \mathrm{g} /$ lane). (a) $c-f o s$, (b) $c-m y c$ and (c) ornithine decarboxylase. tion of p70 was likely to be transcriptionally controlled. Our preliminary experiments suggested that $\mathrm{p} 70$ was a primarily induced protein following serum stimulation and that the failure of $\mathrm{p} 70$ synthesis at $40^{\circ} \mathrm{C}$ was due to the blockage of mRNA synthesis rather than the blockage of posttransicriptional processes (to be published elsewhere). These results suggest that 1) the mutated function of $t s \mathrm{JT} 16$ operates in a signal transduction process from receptor binding of the growth factor at the cell membrane to the stimulation of the transcription of particular genes in nuclei; and 2) a stimulation of transcription occurs via at least two different signaling pathways: one induces $c$-fos, $c-m y c$, and ODC (this process is intact in tsJT16), and the other p70 (this is mutated in ts JT16).

When the culture temperature of $t s \mathrm{JT} 16$ cells growing in a $\log$ phase at $34^{\circ} \mathrm{C}$ was shifted up to $40^{\circ} \mathrm{C}$, the cells could not continue to proliferate. The progression of the $\mathrm{S}, \mathrm{G}_{2}$, and $\mathrm{M}$ phases was not temperature sensitive, and the cell phase where the mutated function is concerned is probably the $G_{1}$ phase in the growing cell cycle. The mutated function of $t s$ JT16 is likely to be concerned not only with signal transduction process soon after serum stimulation of $\mathrm{G}_{0}$-arrested cells, but also with the stage sensitive to the serum in the $G_{1}$ phase of the growing cell cycle. In $3 \mathrm{~T} 3$ cells, the regulatory events for cell cycle progression are located at the restriction point (R-point) in the $G_{1}$ phase $(12,13)$. When

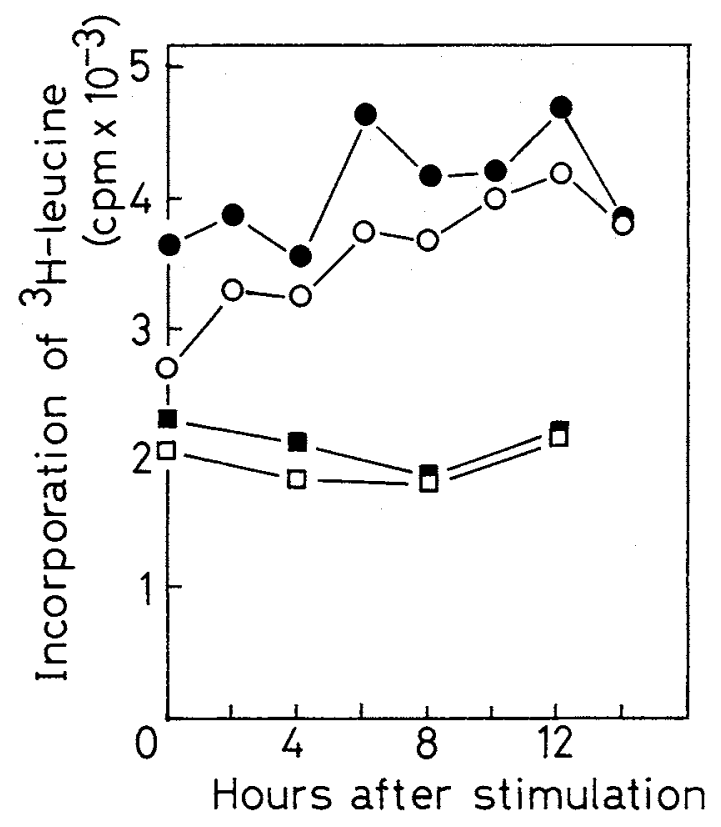

Fig. 7. Incorporation of $\left[{ }^{3} \mathrm{H}\right]$ leucine into acid-precipitable materials. $\mathrm{G}_{0}$-arrested $t$ ITT16 cells were serum-stimulated $(O, \bullet)$ or unstimulated $(\square, \square)$ and cultured for indicated periods at $34^{\circ} \mathrm{C}(O, \square)$ or $40^{\circ} \mathrm{C}(\bullet, \mathbf{\square})$. The cells were labeled with $\left[{ }^{3} \mathrm{H}\right]$ leucine for $1 \mathrm{~h}$. Each value indicates a mean of two determinations. 

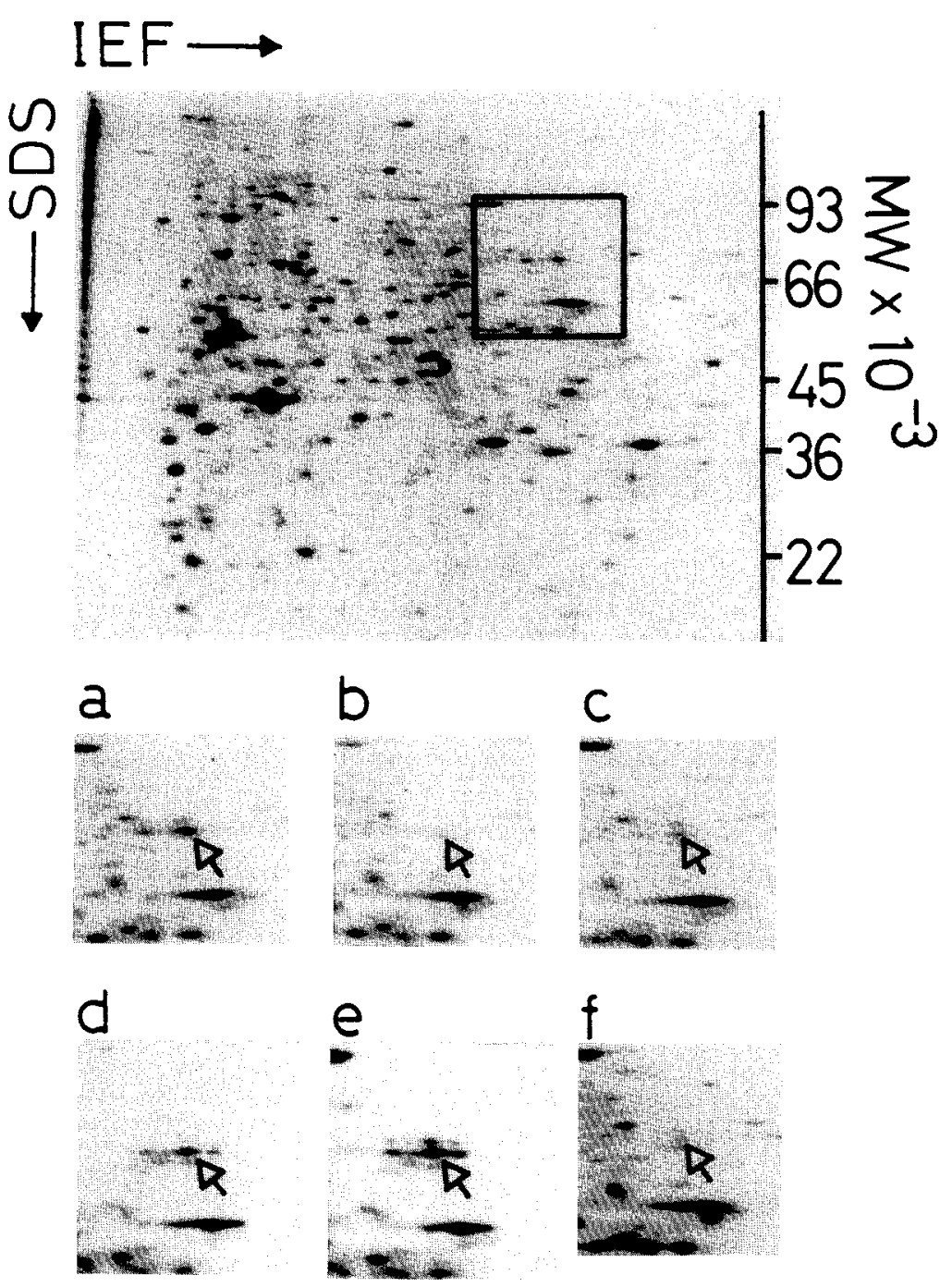

Fig. 8. Analysis of protein by two-dimensional gel electrophoresis. Cells were labeled with $\left.{ }^{35} S\right]$ methionine for the last $2 \mathrm{~h}$, and proteins $\left[5 \times 10^{5}\right.$ $\mathrm{cpm}$ ) were analyzed by two-dimensional polyacrylamide gel electrophoresis. Arrows indicate p 70 protein. The enclosed area of the whole gel (upper photograph) is shown in the lower photographs. (a) $t s \mathrm{JT} 16$ serum-stimulated and cultured for $3 \mathrm{~h}$ at $34^{\circ} \mathrm{C}$, (b) $\mathrm{G}_{0}$-arrested $t s \mathrm{JT} 16$, (c) ts JT16 serum-stimulated and cultured for $3 \mathrm{~h}$ at $40^{\circ} \mathrm{C}$, (d) $3 \mathrm{Y} 1$ serum-stimulated and cultured for $3 \mathrm{~h}$ at $34^{\circ} \mathrm{C}$, (e) $3 \mathrm{Y} 1$ serum-stimulated and cultured for $3 \mathrm{~h}$ at $40^{\circ} \mathrm{C}$, and (f) $t s \mathrm{JT} 16$ serum-stimulated and cultured for $3 \mathrm{~h}$ at $34^{\circ} \mathrm{C}$ in the presence of $10 \mu \mathrm{g} / \mathrm{ml} \mathrm{of} \mathrm{actinomycin} \mathrm{D.}$

growing $3 \mathrm{~T} 3$ cells were transferred into serum-free medium before the R-point in the cell cycle, they did not pass through the R-point but entered the $\mathrm{G}_{0}$ phase (5). When $3 T 3$ cells were shifted into serum-free medium after the R-point, they were able to progress through the remaining $G_{1}, S, G_{2}$, and $M$ phases and then arrested in the $G_{0}$ phase. Cell kinetic experiments using low concentrations of cycloheximide revealed the hypothesis that the commitment of cells to pass the Rpoint is dependent upon the synthesis and accumulation of a labile protein $(4,15)$. Croy and Pardee reported such a candidate protein with molecular weight 68,000 (p68) that was labile and accumulated in the $G_{1}$ phase
(6). The p70 that we showed here had a similar molecular weight and was also serum dependent and labile (unpublished data). It is of interest to see whether the failure of the synthesis of $\mathrm{p} 70$ at $40^{\circ} \mathrm{C}$ is a major cause of the blockage of the $\mathrm{G}_{0}-\mathrm{S}$ transition and of $\mathrm{G}_{1}$ progression.

\section{REFERENCES}

1. Baserga, R. (1985). The Biology of Cell Reproduction. Harvard University Press, Cambridge, Massachusetts.

2. Berger, F.G., Szymanski, P., Read, E., and Watson, G.. (1984). Androgen-related ornithine decarboxylase mRNAs of 
mouse kidney. J. Biol. Chem. 259: 7941-7946.

3. BRooks, R.F. (1977). Continuous protein synthesis is required to maintain the probability of entry into $S$ phase. Cell 12: $311-$ 317.

4. Campisi, J., Medrano, E.E., Morreo, G., and Pardee, A.B. (1982). Restriction point control of cell growth by a labile protein: Evidence for increased stability in transformed cells. Proc. Natl. Acad. Sci. USA 79: 436-440.

5. CAmpisi, J. and Pardee, A.B. (1984). Post-transcriptional control of the onset of DNA synthesis by insulin-like growth factor. Mol. Cell. Biol. 4: 1807-1814.

6. Croy, R.G. and Pardee, A.B. (1983). Enhanced synthesis and stabilization of $\mathrm{Mr} 68,000$ protein in transformed BALB /c-3T3 cells: Candidate for restriction point control of cell growth. Proc. Natl. Acad. Sci. USA 80: 4699-4703.

7. IDE, T., NinomiYa, J., and Ishibashi, S. (1984). Isolation of a $\mathrm{G}_{0}$-specific ts mutant from a Fischer rat cell line, 3Y1. Exp. Cell Res. 150: 60-67.

8. Ide, T., Ninomtya-Tsuti, J., Ferrari, S., Philiponis, V., and BASERGA, R. (1986). Expression of growth-related genes in tsJT60 cells, a temperature-sensitive mutant of the cell cycle. Biochemistry 25: 7041-7046.

9. Kimura, G., ItagaKi, A., and Summers, J. (1975). Rat cell line $3 \mathrm{Y} 1$ and its virogenic polyoma- and SV40-transformed derivatives. Int. J. Cancer 15: 694-706.

10. O'Farrell, P.J. (1975). High resolution two-dimensional electrophoresis of proteins. J. Biol. Chem. 250: 4007-4021.

11. Ohta, T., Takasuka, T., Ishibashi, S., and IDE, T. (1985), Cytochalasin $D$ inhibits the progression from $G_{0}$ to $S$ phase at the mid-prereplicative stage in GC-7 cells stimulated with serum. Cell Struct. Funct. 10: 37-46.

12. Pardee, A.B. (1974). A restriction point for control of normal animal cell proliferation. Proc. Natl. Acad. Sci. USA 71: $1286-1290$.

13. Pardee, A.B. (1987). Molecules involved in proliferation of normal and cancer cells: Presidental Address. Cancer Res. 47: $1488-1491$.

14. Perez, A.G., Krm, J.H., Gelbard, A.S., and Djordjevic, B. (1972). Altered incorporation of nucleic acid precursors by mycoplasma-infected mammalian cells in culture. Exp. Cell Res. 70: 301-310.

15. Rossow, P.W., Riddle, V.G.H., and PARdeE, A.B. (1979). Synthesis of labile serum-dependent protein in early $\mathrm{G}_{1}$ controls animal cell growth. Proc. Natl. Acad. Sci USA 76: 4446-4450.

16. Russel, W.C., Newman, C., and Williamson, D.H. (1975). A simple cytochemical technique for demonstration of DNA in cells infected with mycoplasmas and viruses. Nature (London) 253: 461-462.

17. Schneiderman, M.H., Dewey, W.C., and Highrield, D.P. (1971). Inhibition of DNA synthesis in synchronized Chinese hamster cells treated in $\mathrm{G}_{1}$ with cycloheximide. Exp. Cell Res. 67: $147-155$.

(Received for publication, September 8, 1989 and in revised form, November 9, 1989) 